\title{
Die

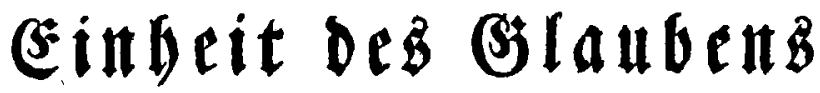 \\ ber
}

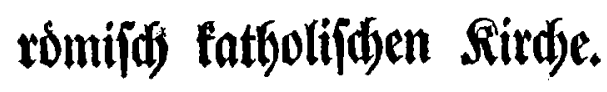

bifforifd beleudgtet

o on

c. S. X. Xieb.

\author{
Berlin, 1827. \\ ce c c ud t \\ bei 6 . Fieimer.
}


